\title{
Relationships of Vegetation Indices and Biomass of Mangrove Forest Plantation in Thailand
}

\author{
Weerakaset Suanpaga and Wathinee Suanpaga
}

\begin{abstract}
The objective of this research was to analyzed the relationship of vegetation index and biomass of mangrove forest plantation in in Don Sak national reserved mangrove forest, Don Sak district, Surat Thani province. The methodology was conducted by analysis relationship between the five vegetation indices, and five reflectances calculated from LANDSAT 8 satellite imagery which has a resolution of 30 meters and the data from field biomass survey. The proportional stratified sampling system classified by the age class; tree aged between 1-19 years, 14 age classes, three sample plots per age class, plot size $15 \times 15$ meters. The diameter and height of all trees in sample plot were collected for biomass calculation by using allometric equation. The result of this study found that the general linear and quadratic relationship of green radiance $(\mathbf{G})$ and biomass were significant (Biomass $=-1,318.715 *(G)+$ 129.191, $\mathbf{R}^{2}=0.702 ;$ Biomass $=462.134-9,002.43(\mathrm{G})+$ 43,823.11 $\left.\left(G^{2}\right) \quad, R^{2}=0.786\right)$ Meanwhile, there was no relationship between other vegetative indexes and biomass.
\end{abstract}

Index Terms-Biomass, LANDSAT 8, mangrove, vegetative index.

\section{INTRODUCTION}

Mangrove forests are the most productivity and biologically diverse ecosystem in the world [1]. Mangrove forests provide various direct and indirect ecosystem services such as natural protection barriers and nursery habitat for marine organisms [2]-[5]. Especially, mangrove forests thrive near coastal areas, which function as carbon pools [6]. Biomass assessment has become very important to assess forest ecosystem productivity, determine carbon budgets, and support studies of the role of forests in the global carbon cycle [7]-[9].

Biomass plays a very important role in global carbon cycle as it is associated with carbon sequestration; it helps in quantifying pools and fluxes of greenhouse gases from the terrestrial biosphere to the atmosphere formed by various land-use and land cover changes [10]. Thus, it is crucial to study the biomass of mangrove trees in order to describe the changes of climate patterns at the regional and global scales.

Application of remote sensing is also crucial to obtain

Manuscript received November 19, 2018; revised February 2, 2019. The authors would like to acknowledge the Sustainable Land Use and Natural Resource Management Program, Kasetsart University to support this research work. This work was supported in part by the Center for Advanced Studies in Tropical Natural Resources, NRU-KU, Kasetsart University.

Weerakaset Suanpaga is with the Department of Civil Engineering, Faculty of Engineering, Kasetsart University, Bangkok, Thailand (e-mail: weerakaset.s@ku.ac.th).

Wathinee Suanpaga is with the Department of Silviculture, Faculty of Forestry, Kasetsart University, Bangkok, Thailand (corresponding author; e-mail: wathinee.s@ku.ac.th). pertinent information of land use cover and land use change over extensive coverage areas. The remote sensing technology has been applied for biomass assessment. Vegetation indices are the mathematical transformation of the original spectral reflectance which are used for interpreting vegetation biomass and cover [11]-[13]. Satellite based vegetation indices models are the most commonly used models for biomass estimation of mangrove forests in many studies [14]-[17].

Coastal areas within Don Sak district of Surat Thani Province, specifically within the Don Sak National Forest Reserve the 2,400 ha of mangrove forest that originally occurred here has been reduce to approximately 160 ha, whereas the remaining 2,240 ha (14,000 Rai) consists largely of abandoned ponds, clearfelled (degraded) wasteland and a limited number of active shrimp ponds. The Mangrove Forest Management Unit of the Royal Forest Department in Surat Thani, keen to restore the mangroves in this area [18].

After 19 years of replanting, the biomass of this plantation is necessary to evaluation, thus the relationships of vegetation indices and biomass is necessary to study for further monitoring the biomass change and managing the sustainable forest in this area.

\section{Methodology}

\section{A. Study Site}

The Don Sak National Forest Reserve (57000 - 57700 E, $1022000-1032000$ N) is located in Surat Thani Province in the Upper South Region of Thailand (Fig. 1). The study area has a sub-tropical monsoonal maritime climate with an annual average temperature of $31^{\circ} \mathrm{C}$. The coldest month is January, the warmest May. The average annual number of hours of sunshine is approximately 2,000. Rainfall is seasonal and varies considerably between years, 1,500 2,500 $\mathrm{mm} /$ year. Most of the precipitation occurs during the fall monsoon, when the coastal area is also subject to typhoons. The tropical climate and the extensive coastline with its numerous sheltered bays and muddy inlets create ideal conditions for the development of mangrove forests.

This area historically had one of the most extensive and richest variety of mangrove forests along the Gulf coast of Southern Thailand, although it is much reduced today due to conversion to other uses such as shrimp farms or salt ponds, and erosion due to the overall reduction in total area and thus the ability of the total system to function as a means of coastal erosion control [18].

The forest restoration project was started in 1997 by planting mangrove tree species using $1.5 \times 1.5 \mathrm{~m}$ in spacing. 

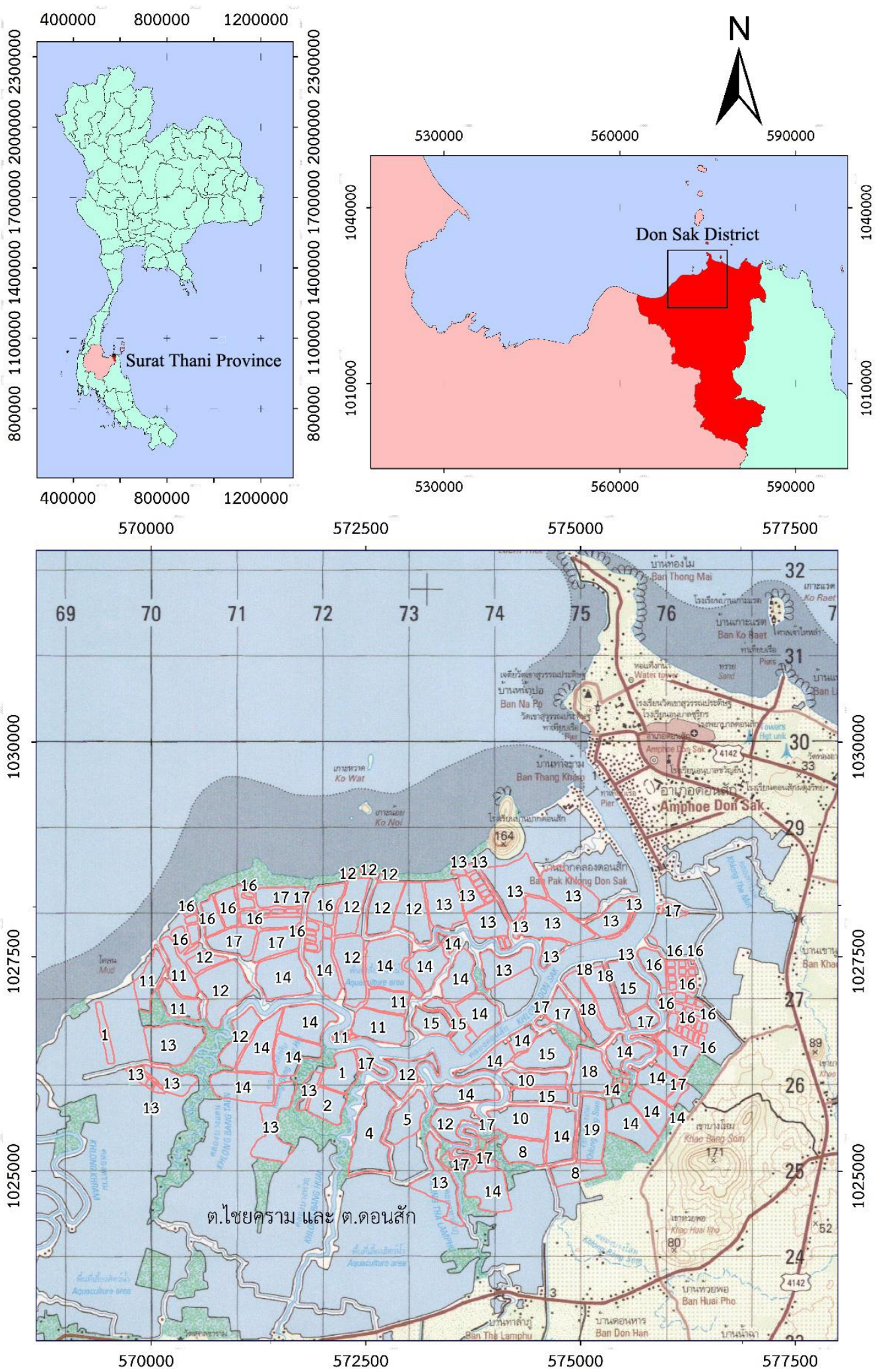

Fig. 1. Mangrove plantation at Don Sak National Forest Reserve, Don Sak District, Surat Thani Province, Thailand.

The planting of mangrove tree i.e. Rhizophora mucronate and Ceriops tagal during 1997 - 2015 covered 13.46 ha.

\section{B. Biomass}

The proportional stratified sampling by age of the trees in each plot was used. The 14 age classes were classified. Three plots of each age class, $15 \times 15$ meters in size, were spread over the whole distance from the sea. There were the measurement of diameter and height of every tree in the sample plot. Then, allometric equations were used for calculate the biomass.

1) R. mucronate. [19] as in equation (1) and (2).

$$
\begin{aligned}
& \text { Wtop }=0.251 \rho \mathrm{D}^{2.46} \\
& \mathrm{Wr}=0.199 \rho^{0.899} \mathrm{D}^{2.22}
\end{aligned}
$$

where, Wtop = above ground biomass $(\mathrm{kg}), \mathrm{Wr}=$ root 
biomass $(\mathrm{kg})$, pof $R$. mucronate $=0.701 \pm 0.033, \mathrm{D}=$ diameter at $20 \mathrm{~cm}$ above upper root $(\mathrm{cm})$.

2) C. tagal. as in equation (3) - (6).

$$
\begin{aligned}
\mathrm{Wl} & =0.01728\left(\mathrm{DBH}^{2} \mathrm{H}\right)^{0.5125} \\
\mathrm{~Wb} & =0.0617\left(\mathrm{DBH}^{2} \mathrm{H}\right)^{0.7161} \\
\mathrm{Wt} & =0.0356\left(\mathrm{DBH}^{2} \mathrm{H}\right)^{0.7067} \\
\mathrm{Wr} & =0.1309\left(\mathrm{DBH}^{2} \mathrm{H}\right)^{0.6821}
\end{aligned}
$$

where, $\mathrm{Wl}=$ leaf biomass $(\mathrm{kg}), \mathrm{Wb}=$ branch biomass $(\mathrm{kg})$, $\mathrm{Wt}=$ truck biomass $(\mathrm{kg}), \mathrm{Wr}=$ root biomass $(\mathrm{kg}), \mathrm{DBH}=$ diameter at $130 \mathrm{~cm}$ above ground $(\mathrm{cm}), \mathrm{H}=$ total height $(\mathrm{m})$

\section{Vegetation Indices}

The image from LANDSAT 8 OLI satellite which captured on March 14, 2017. It was modified by geometric correction and atmospheric correction (DN to reflectance) [20] applied from the following

3) Atmospheric Correction. Calculating reflectance value from satellite data from the following equation (7)

$$
\mathrm{P} \lambda^{\prime}=\mathrm{Mp} * \mathrm{Qcal}+\mathrm{Ap}
$$

where, $\mathrm{P} \lambda^{\prime}=$ TOA (Top of atmosphere) planetary reflectance, without correction for solar angle.

$\mathrm{Mp}=$ Band - specific multiplicative rescaling factor from the metadata

Ap $=$ Band - specific additive rescaling factor from the metadata

Qcal = Quantized and calibrated standard product pixel value (DN)

Then, correcting the reflectance value with sun angle following equation (8)

$$
\mathrm{P} \lambda=\mathrm{P} \lambda{ }^{\prime} / \cos \theta \mathrm{SZ}=\mathrm{P} \lambda^{\prime} / \sin \theta \mathrm{SE}
$$

where, $\mathrm{P} \lambda=$ TOA (Top of atmosphere) planetary reflectance

$\mathrm{P} \lambda^{\prime}=$ TOA (Top of atmosphere) planetary reflectance without correction for solar angle.

$\theta \mathrm{SZ}=$ Local solar zenith angle; $\theta \mathrm{SZ}=90^{\circ}-\theta \mathrm{SE} \quad \theta \mathrm{SE}=$ Local sun elevation angle.

Analysis of Vegetation Indices. The study has been used ten vegetation indices as in equation (9) - (18).

$$
\text { Difference Vegetation Index }(D V I)=\rho N I R-\rho R
$$

$$
\text { Ratio Vegetation Index }(\mathrm{RVI})=\rho \mathrm{NIR} / \rho \mathrm{R}
$$

Normalized Difference Vegetation Index $(\mathrm{NDVI})=(\rho \mathrm{NIR}$

$$
-\rho R) /(\rho N I R+\rho R)
$$

Green normalized difference vegetation Index (GNDVI)

$$
=(\rho \text { IR }-\rho G) /(\rho N I R+\rho G)
$$

Soil - Adjusted Vegetation Index $(\mathrm{SAVI})=(1.5)(\rho \mathrm{NIR}$ -

$$
\rho R)(\rho N I R+\rho R+0.5)
$$

$$
\text { Green } \operatorname{radiance}(G)=\rho G
$$

$$
\text { Red radiance }(R)=\rho R
$$

Near - infared radiance $(\mathrm{NIR})=\rho \mathrm{NIR}$

Green band Plus Red band $=\rho G+\rho R$

Green band Minus Red band $=\rho G-\rho R$

\section{Relationship Analysis}

The analysis of vegetation indices which influences to biomass used the stepwise regression method.

\section{RESULTS AND DISCUSSION}

\section{A. Biomass}

The average diameter, height, and biomass of each age class were different and tended to be higher with age. However, from Fig. 2 - 4, it was observed that the 16 and 17 year-old plots had lower growth and biomass than that of younger plots. Due to the planting area in 1999 and 2000 were close to the beach, so $C$. tagal that had low growth rate was selected to plant. Moreover, the soil in that area is fine sand with mud and no flood of sea water, which is not suitable for the growth of mangrove trees, thus the diameter, height, and biomass of 16 and 17 year-old trees were low.

\section{B. Linear Regression and Model}

The linear regression of green radiance and biomass had highest $\mathrm{R}^{2}$ as shown in Table I. From the stepwise regression, the best model for green radiance and biomass was quadratic model as shown in Table II and Fig. 5. The productivity or biomass of mangrove forest plantation in Don Sak National Forest Reserve was correlated with the reflectance of the green light more than those of the near infrared and red light. Because green reflectance of the LANDSAT 8 satellite, which has a wavelength range of $0.53-0.59 \mu \mathrm{m}$, is the widest compared to wavelength range of the red and near infrared light, $0.64-0.67 \mu \mathrm{m}$ and $0.85-0.88 \mu \mathrm{m}$, respectively. This was inconsistent with [21] that mangrove species are not clearly distinguishable in the green region and are confounded in the NIR region of the spectrum.

The mangrove species can be easily identified and mapped with a narrow contiguous wavelength bands in the NIR region [1]. But most of this study area is pure stand plantations of $R$. mucronate. Thus, the $\mathrm{R}^{2}$ of the NIR spectrum or $\mathrm{R}^{2}$ of the vegetation indices from NIR was lower than $\mathrm{R}^{2}$ of green and red wave.

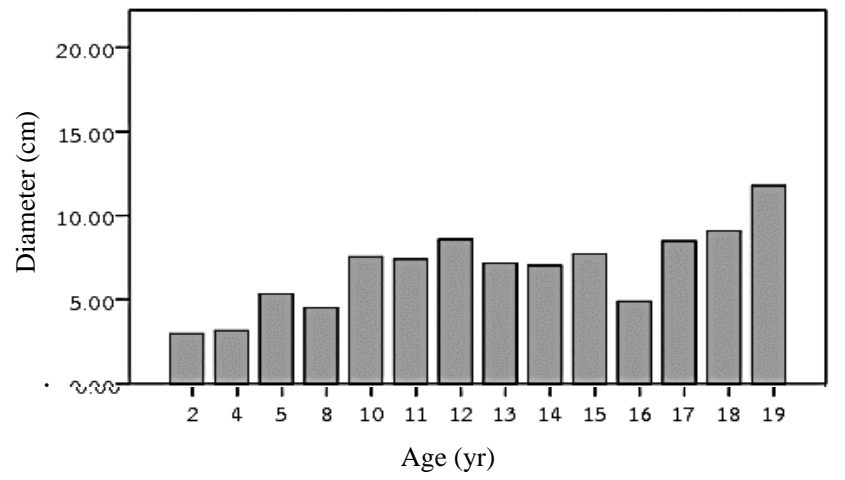

Fig. 2. Diameter of mangrove forest plantation in various ages. 


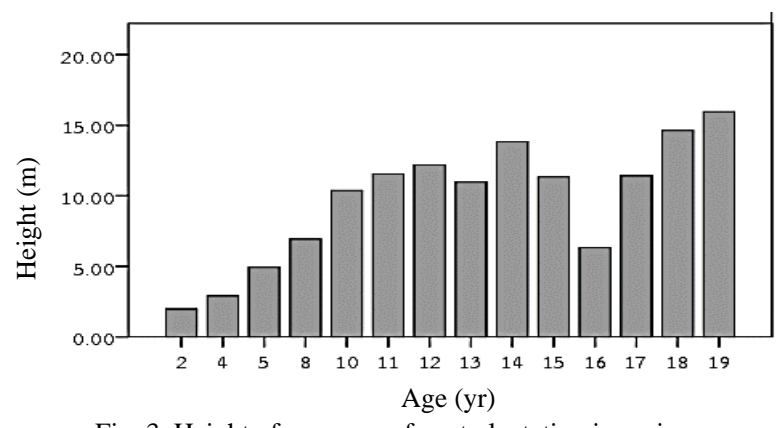

Fig. 3. Height of mangrove forest plantation in various ages.

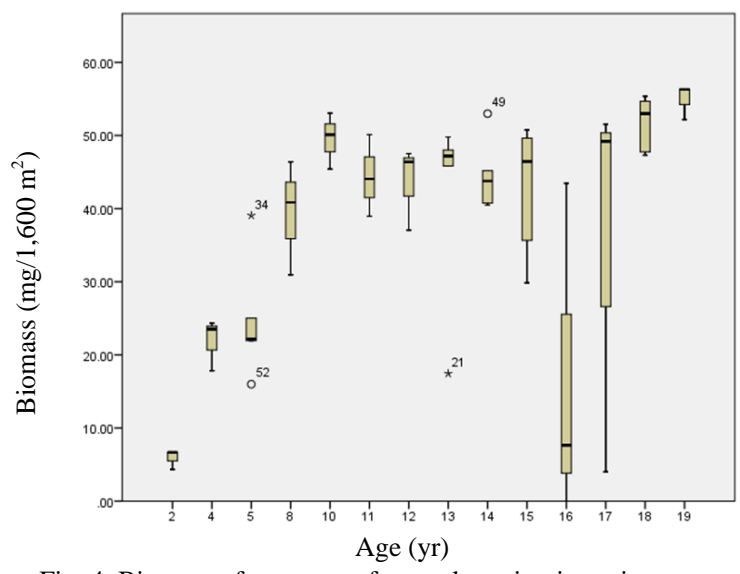

Fig. 4. Biomass of mangrove forest plantation in various ages.

TABLE I: LINEAR REGRESSION BETWEEN 10 VEGETATION INDICES AND BIOMASS OF MANGROVE FOREST PLANTATION

\begin{tabular}{ll}
\hline \hline Vegetation indices & $\mathrm{R}^{2}$ \\
\hline Green & 0.702 \\
Red & 0.630 \\
NIR & 0.367 \\
SAVI & 0.515 \\
NDVI & 0.598 \\
GNDVI & 0.577 \\
RVI & 0.582 \\
DVI & 0.459 \\
Green Plus Red & 0.668 \\
Green Minus Red & 0.336 \\
\hline \hline
\end{tabular}

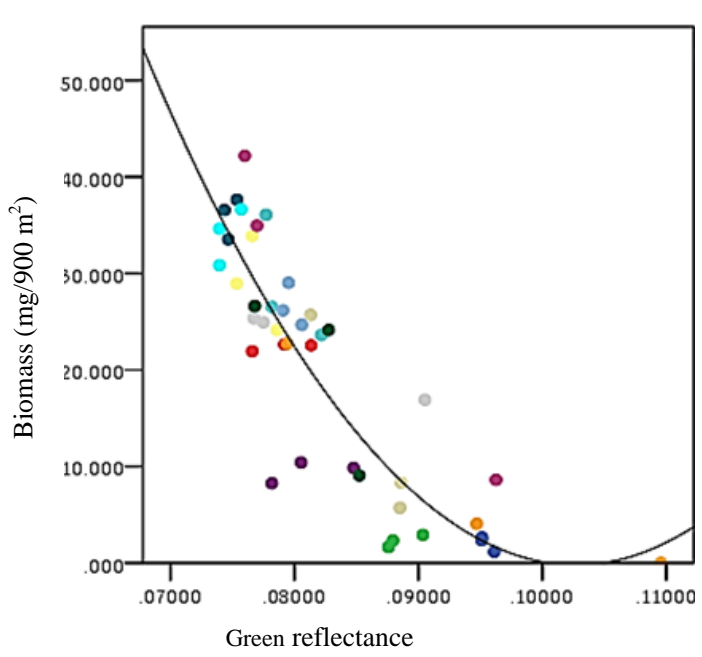

Fig. 5. Quadratic relationship between biomass and green reflectance of mangrove forest plantation.

TABLE II: MODEL OF GREEN RADIANCE (G) AND BIOMASS (W) OF MANGROVE ForEST PLANTATION FROM STEPWISE REGRESSION

\begin{tabular}{llc}
\hline \multicolumn{2}{c}{ Model } & $\mathrm{R}^{2}$ \\
\hline Linear & $\mathrm{W}=129.191-1318.715^{*} \mathrm{G}$ & 0.702 \\
Logarithm & $\mathrm{W}=-270.869-116.546^{*} \log \mathrm{G}$ & 0.728 \\
Quadratic & $\mathrm{W}=462.134-9,002.430 * \mathrm{G}+43,823.111^{*} \mathrm{G}^{2}$ & 0.786 \\
\hline \hline
\end{tabular}

\section{CONCLUSION}

The green wave had strong correlation in quadratic model to biomass of mangrove forest plantation in Don Sak National Forest Reserve in Surat Thani Province,Thailand.

\section{ACKNOWLEDGMENT}

We would like to thank Ms. Kwannate Tongsri for data collection and analysis

\section{REFERENCES}

[1] J. Kamaruzaman and I. Kasawani, "Imaging spectrometry on mangrove species identification and mapping in Malaysia," WSEAS Trans. Biol. Biomed., vol. 8, pp. 118-126, 2007.

[2] K. C. Ewel, R. R. Twilley, and J. E. Ong, "Different kinds of mangrove forests provide different goods and services," Glob. Ecol. Biogeogr. Lett., vol. 7, pp. 83-94, 1998.

[3] O. Aburto-Oropeza; E. Ezcurra, G. Danemann, V. Valdez, J. Murray, and E. Sala, "Mangroves in the gulf of California increase fishery yields," in Proc. Natl. Acad. Sci., vol. 105, pp. 10456-10459, 2008.

[4] E. B. Barbier, S. D. Hacker, C. Kennedy, E. W. Koch, A. C. Stier, and B. R. Silliman, "The value of estuarine and coastal ecosystem services," Ecol. Monogr., vol. 81, pp. 169-193, 2011.

[5] Q. T. Vo, C. Kuenzer, Q. M. Vo, F. Moder, and N. Oppelt, "Review of valuation methods for mangrove ecosystem services," Ecol. Indic., vol. 23, pp. 431-446, 2012.

[6] V. Patil, A. Singh, N. Naik, and S. Unnikrishnan, "Estimation of carbon stocks in Avicennia marina stand using allometry, CHN analysis, and GIS methods," Wetlands, vol. 34, pp. 379-391, 2014.

[7] D. Zianis and M. Mencuccini, "On simplifying allometric analyses of forest biomass," For. Ecol. and Manag., vol. 187, no. 2-3, pp. 311-332, 2004.

[8] Z. Somogyi, E. Cienciala, R. Mäkipää, P. Muukkonen, A. Lehtonen, and P. Weiss, "Indirect methods of large-scale forest biomass estimation," Eur. J. For. Res., vol. 126, no. 2, pp. 197-207, 2006.

[9] R. J. Hall, R. S. Skakun, E. J. Arsenault, and B. S. Case, "Modeling forest stand structure attributes using Landsat ETM+ data: Application to mapping of aboveground biomass and stand volume," For. Ecol. Manag., vol. 225, no. 1-3, pp. 378-390, 2006.

[10] M. A. Cairns, I. Olmsted, J. Granados, and J. Argaez, "Composition and aboveground tree biomass of a dry semi-evergreen forest on Mexico's Yucatan Peninsula," For. Ecol. Manag., vol. 186, no. 1-3, pp. 125-132, 2003.

[11] A. F. Rahman, J. A. Gamon, D. A. Sims, and M. Schmidts, "Optimum pixel size for hyperspectral studies of ecosystem function in southern California chaparral and grassland," Remote Sens. Environ., vol. 84, pp. 192-207, 2003.

[12] Y. H. He and X. L. Guo, "Wilmshurst, Studying mixed grassland ecosystems: suitable hyperspectral vegetation indices," Canadian J. Remote Sens., vol. 32, pp. 98-107, 2006.

[13] N. K. Patel, R. K. Saxena, and A. Shiwalkar, "Study of fractional vegetation cover using high spectral resolution data," J. Indian Society Remote Sens., vol. 35, pp. 73-79, 2007.

[14] A. Hartoko, S. Chayaningrum, D. A. Febrianti, D. Ariyanto, and Suryanti, "Carbon biomass algorithms development for mangrove vegetation in Kemujan, Parang Island Karimunjawa National Park and Demak Coastal Area, Indonesia," Procedia Environ. Sci., vol. 23, pp. $39-47,2015$

[15] Y. Zhu, K. Liu, L. Liu, S. Wang, and H. Liu, "Retrieval of mangrove aboveground biomass at the individual species level with WorldView-2 Images," Remote Sens., vol. 7, pp. 12192-12214, 2015

[16] F. F. Muhsoni, A. B, Sambah, M. Mahmudi, and D. G. R. Wiadnya, "Comparison of different vegetation indices for assessing mangrove density using Sentinel-2 imagery," Int. J. Geomate, vol. 14, no. 45, pp. 42-51, 2018.

[17] M. E. Muhd-Ekhzarizal, I. Mohd-Hasmadi, O. Hamdan, M. K. Mohamad-Roslan, and S. Noor-Shaila, "Estimation of aboveground biomass in mangrove forests using vegetation indices from SPOT-5 Image," J. Trop. For. Sci., vol. 30, no. 2, pp. 224-233, 2018.

[18] R. R. Lewis III, P. L. A. Erftemeijer, A. Sayaka, and P. Kethkaew, "Mangrove rehabilitation after shrimp aquaculture: A case study in progress at the Don Sak National Forest Reserve, Surat Thani, Southern Thailand, Case Study 13," Annexes to the Thematic Review on Coastal Wetland Habitats and Shrimp Aquaculture, pp. 108-128, 2002. 
[19] A. Komiyama, S. Poungparn, and S. Kato, "Common allometric equations for estimating the tree weight of mangroves," J. Trop. Ecol., vol. 21, pp. 471-477, 2005.

[20] United States Geological Survey (USGS), LANDSAT 8, July 3, 2016.

[21] J. Pastor-Guzman, P. M. Atkinson, J. Dash, and R. Rioja-Nieto, "Spatiotemporal variation in mangrove chlorophyll concentration using Landsat 8," Remote Sens., vol. 7, no. 11, pp. 14530-14558, 2015.

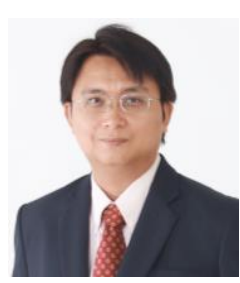

Weerakaset Suanpaga was born in Chiang Mai, Thailand on Septmeber 2, 1976. He received the BEng (civil engineering) from Chiang Mai University, Thailand in 1995, the MEng (civil engineering) from Chiang Mai University, Thailand in 2004, and the DEng (RS \&GIS) from Asian Institute of Technology, Thailand in 2011, respectively. He joined the Faculty of Engineer,
Kasetsart University, Thailand as a lecturer in 2004 and later appointed as an associated professor in 2016. He is an assistant dean for academic service of Faculty of Engineering and deputy director of Disaster Managemen Excellent Centre, since 2016. His current research interests include remote sensing, digital image processing, ortho-photo mapping, 3D reconstruction using Drone/UAV., and geographic information system.

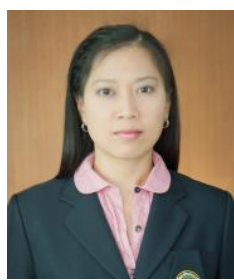

Wathinee Suanpaga received her Ph.D. degree in Forestry from Kasetsart University, Thailand in 2007. Since then, she has been with the Faculty of Forestry, Kasetsart University, where she is Assistant Professor. Her current researches include silviculture, tree improvement, forest restoration, and agroforestry. 